\title{
Aplikasi Pulsed Electric Field (PEF) Sistem Kontinyu Pada Sari Tebu HiJau (Saccharum Officinarum L.) (Kajian Tegangan dan Frekuensi Pef) \\ Pulsed Electric Field (Pef) Continous System Application On Green Sugar Cane Extract (Saccharum officinarum L.) (A Study Of Voltage And Frequency Of Pef)
}

\author{
Dina Wahyu Indriani ${ }^{1)}$, Sumardi Hadi Sumarlan ${ }^{1)}$, Riska Novia Cahyanti ${ }^{2)}$, Arie Febrianto Mulyadi ${ }^{2)}$ Nunun \\ Barunawati $^{3)}$ \\ 1) Jurusan Keteknikan Pertanian Fakultas Teknologi Pertanian, Universitas Brawijaya \\ 2) Jurusan Teknologi Industri Pertanian Fakultas Teknologi Pertanian, Universitas Brawijaya \\ 3) Jurusan Budidaya Pertanian Fakultas Pertanian - Universitas Brawijaya \\ Jl. Veteran No 1 Malang 65145 \\ Email: dinawahyu@ub.ac.id
}

\begin{abstract}
ABSTRAK
Sari tebu hijau merupakan diversifikasi produk olahan tebu hijau. Pada proses pastuerisasi sari tebu hijau dapat dilakukan dengan dua cara yaitu termal dan nontermal. Kandungan tertinggi pada sari tebu yaitu gula sebesar 75-92 \%, bila dipanaskan dengan metode termal adanya ion $\mathrm{OH}$ - akan terjadi proses dekomposisi diawali dengan pembentukan asam organik (asam laktat) diikuti senyawa kompleks yang akhirnya dapat menghasilkan warna coklat. Berdasarkan hal tersebut dibutuhkan alternatif pengolahan sari tebu hijau nontermal. Salah satu pengolahan nontermal menggunakan Pulsed Electric Field (PEF). Penelitian ini bertujuan untuk mengetahui pengaruh kombinasi tegangan dan frekuensi PEF terhadap kualitas sari tebu hijau, serta untuk mengetahui kombinasi tegangan dan frekuensi PEF yang paling tepat agar dihasilkan kualitas sari tebu hijau yang terbaik. Hasil penelitian menunjukkan bahwa tegangan $(<40 \mathrm{kV})$ dan frekuensi $(<40 \mathrm{kHz}$ ) yang rendah pada perlakuan PEF tidak berpengaruh signifikan terhadap total mikroba, total padatan terlarut, total gula, viskositas dan warna pada sari tebu hijau. Perlakuan terbaik pada penelitian ini yaitu perlakuan PEF menggunakan tegangan $40 \mathrm{kV}$ dan frekuensi $40 \mathrm{kHz}$. Hasil perlakuan terbaik pada pengujian TPC pada perlakuan PEF tegangan $40 \mathrm{kV}$ dengan frekuensi $40 \mathrm{kHz}$ yaitu 87,48 \% dengan total mikroba 8,5 x $106 \mathrm{cfu} / \mathrm{ml}$. Penurunan total mikroba pada tegangan $40 \mathrm{kV}$ dan frekuensi $40 \mathrm{kHz}$ sebesar 0,9 log cycle, dengan karakteristik pH yaitu 5,83 , total padatan terlarut (TPT) sebesar $13,4^{\circ}$ Brix, viskositas sebesar $5 \mathrm{Cp}$, warna kecerahan ( $\left.\mathrm{L}^{*}\right)$ sebesar 23,55, kemerahan (a*) sebesar 7, kekuningan ( $\mathrm{b}^{*}$ ) sebesar 7,3, dan total gula sebesar $12,24 \%$.
\end{abstract}

Kata Kunci: Frekuensi, Pulsed Electric Field (PEF), Sari tebu hijau, Tegangan, emerging processing

\section{ABSTRACT}

Green sugar cane extract is diversification of products green cane processed. On the green cane juice pasteurization process, it can be done in two ways. They are thermal and nontermal. The highest content of sugar cane extract was equal to $75-92 \%$, when it was heated in thermal method the presence of $\mathrm{OH}$-ions would occur decomposition process began with the formation of organic acids (lactic acid) followed by complex chem. Compound that produced brown in the colour. Based on the explanation above, it needed the non termal green sugar cane extract. One of non-termal process used Pulsed Electric Field (PEF). The aims of this research are to know the effect of combination voltage and frequency of PEF toward the green sugar cane extract quality and the most appropriate of combination voltage and frequency PEF to get the best of green sugar cane quality. The result showed that PEF statistically were not influnced to the total of microba, total dissolved solids, total sugar, viscosity and color on a green sugar cane extract. The best treatment of this research was PEF treatment using a voltage of $40 \mathrm{kV}$ and a frequency of $40 \mathrm{kHz}$. The total 
microba voltage of $40 \mathrm{kV}$ with a frequency of $40 \mathrm{kHz}$ which was $87,48 \%$ with total microba 8,5 $\times 106 \mathrm{cfu} /$ $\mathrm{ml}$. A decrease in the total microba voltage of $40 \mathrm{kV}$ and a frequency of $40 \mathrm{kHz}$ at 0,9 log cycle, with the characteristic that was 5,83 $\mathrm{pH}$, total dissolved solids (TPT) 13,4 oBrix, the viscosity of $5 \mathrm{cp}$, color brightness $\left(L^{*}\right)$ at $23: 55$, redness $\left(a^{*}\right)$ amounted to 7 , yellow $\left(b^{*}\right)$ of 7,3 , and total sugar by $12.24 \%$.

Keywords: Frequency, Green Sugar Cane Extract, Pulsed Electric Field (PEF), voltage, emerging processing

Diterima : 21 Maret 2017; Disetujui : 16 April 2017; Online Published : 25 Juli 2017

DOI : 10.24198/jt.vol11n1.5

\section{PENDAHULUAN}

Pertanian atau perkebunan di Indonesia sangat beragam tanaman yang dihasilkan, di daerah Jawa banyak daerah yang menghasilkan tanaman tebu. Proses pembuatan tebu akan dihasilkan gula $5 \%$, ampas tebu $90 \%$ dan sisanya tetes (molasses) dan air. Tebu memiliki beberapa varietas, salah satunya tebu PS 862 . PS 862 sebelumnya dikenal dengan nama seri PS 86-8504 merupakan keturunan dari induk $\mathrm{F} 162$ (polycross) yang dilepas Menteri Pertanian tahun 1998 (Anonim,1998). Tebu varietas PS 862 memenuhi spesifikasi yang dibutuhkan pada sari tebu, yaitu menghasilkan banyak sari, rasanya manis dan mempunyai warna hijau yang menarik (Rahmad, dkk., 2013).

Sari tebu merupakan suatu alternatif diversifikasi produk dari komoditas tebu. Pada umumnya sari tebu adalah minuman segar yang didapat dari menggiling tebu dan diambil sarinya. Proses pembuatan sari tebu sangat sederhana, hanya dengan menggiling atau memeras batang tebu hingga keluar sarinya (Anonim, 2008). Pada saat ini belum ada sari tebu hijau yang dijual dalam bentuk kemasan, sehingga untuk membuat sari tebu hijau yang memiliki umur simpan yang lebih lama maka dibutuhkan pengawetan.

Pengawetan sari tebu dapat dilakukan dengan dua metode, yaitu termal dan nontermal, pengolahan dengan termal dapat dilakukan dengan proses pasteurisasi tetapi pada proses ini menggunakan suhu sekitar $80^{\circ} \mathrm{C}$. Menurut Honig (1986) menyatakan bahwa kandungan tertinggi pada sari tebu yaitu gula sebesar 75-92 \%, bila dipanaskan dengan metode termal dapat merusak warna sari tebu. Berdasarkan hal tersebut dibutuhkan alternatif pengolahan sari tebu hijau nontermal. Salah satu pengolahan nontermal menggunakan Pulsed Electric Field (PEF).

Metode nontermal PEF adalah salah satu metode perlakuan nontermal untuk pengawetan makanan, karena PEF berpotensi dalam menginaktivasi mikroba tanpa mengubah cita rasa dan kekayaan nutrisi pada makanan. Proses PEF didasarkan pada aplikasi denyut pendek tegangan tinggi $(20-80 \mathrm{kV} / \mathrm{cm})$ dengan waktu yang sangat singkat (kurang lebih 1 detik) pada makanan cair yang ditempatkan diantara dua elektroda. Penurunan mikroorganisme berbanding lurus dengan besar tegangan, frekuensi dan waktu pasteurisasi (Barbosa, et al., 1999), sehingga dapat digambarkan bahwa semakin besar tegangan dan frekuensi yang digunakan dalam proses pasteurisasi maka semakin besar pula penurunan jumlah mikroorganisme.

Menurut Aronsson, et al. (2001) menyatakan bahwa semakin besar frekuensi yang digunakan pada perlakuan PEF akan mampu menurunkan bakteri $E$. coli dengan menggunakan $30 \mathrm{kV}$ dan frekuensi $20 \mathrm{kHz}$ dari 5 log menjadi 2,7 log atau sekitar $25 \%$. Pengolahan sari tebu menggunakan PEF dapat menginaktivasi mikroba tanpa merusak struktur jaringan dalam sari tebu sehingga kualitas yang ada tetap terjaga, sehingga pada penelitian ini menggunakan metode pasteurisasi nontermal menggunakan pulsed electric field (PEF). Faktor yang diamati yaitu tegangan dan frekuensi, sehingga mendapatkan kombinasi tegangan dan frekuensi PEF yang tepat untuk sari tebu hijau.

\section{METODOLOGI PENELITIAN}

\section{Alat dan Bahan Penelitian}

Alat yang digunakan dalam penelitian yaitu rangkaian alat Pulsed Electric Field (PEF), botol, 
pisau, sarung tangan, aluminium foil, kapas, autoclave, baskom, gunting, tabung ukur, dan kertas label. Alat yang digunakan untuk analisa yaitu pipet, mikopipet, cawan petri, kapas, kertas coklat, tabung ukur, gelas ukur, Laminar Air Flow (LAF), timbangan, sarung tangan, aluminium foil, tabung reaksi, kapas, blue tip, kompor listrik, dan inkubator merek bionex. Bahan - bahan yang digunakan dalam penelitian ini adalah tebu varietas PS -862 yang didapatkan dari penjual sari tebu hijau Jl. Candi Trowulan kota Malang, alkohol 96\%, dan aquades. Bahan yang digunakan untuk analisa adalah plate count agar (PCA) merek oxoid.

\section{Rancangan Percobaan}

Penelitian menggunakan Rancangan Acak Kelompok (RAK) dengan 2 faktorial yaitu tegangan (20 kV, 30 kV, dan $40 \mathrm{kV}$ ) dan Frekuensi PEF (20 $\mathrm{kHz}, 30 \mathrm{kHz}$, dan $40 \mathrm{kHz}$ ), kemudian dilakukan 2 kali ulangan.

\section{Pelaksanaan Penelitian}

Proses pembuatan sari tebu hijau yaitu tebu hijau dicuci dengan air kemudian tebu hijau dikupas kulitnya, lalu tebu hijau dibelah menjadi tiga. Selanjutnya tebu hijau yang sudah dibelah dimasukkan ke mesin pengepres. Sari tebu hijau dimasukkan kedalam botol steril. Proses nontermal menggunakan PEF yang pertama sari tebu hijau sebagai bahan uji disiapkan dalam botol dengan ukuran $140 \mathrm{ml} /$ sampel. Tempatkan sari tebu pada chamber, hubungkan ke arus listrik. Atur tegangan pada perlakuan pertama sebesar 20 $\checkmark$ dan frekuensi sebesar $20 \mathrm{kHz}$, lalu tekan tombol ON. Buka kran ouput dan tempatkan di botol yang telah disterilisasi dan tutup dengan tutup botol yang telah disterilisasi agar tidak terjadi kontaminasi dengan lingkungan. Bersihkan ruang perlakuan dengan alkohol $96 \%$ setiap selesai melakukan penelitian. Ulangi untuk setiap kombinasi tegangan dan frekuensi PEF.

Pengamatan

Parameter uji yang dilakukan adalah total mikroba (TPC), total padatan terlarut (TPT), total gula, viskositas dan warna.
- Prosedur analisa Total Plate Count, analisa mengunakan perhitungan langsung dengan metode hitungan cawan dengan media Plate Count Agar (PCA) menggunakan 4 kali pengenceran. Proses inkubasi dilakukan selama 72 jam dengan perhitungan mikroba sebesar 30-300 koloni.

- Total Padatan Terlarut, dihitung menggunakan refraktometer, dengan meletakkan bahan pada prisma refraktometer maka akan muncul skala hasil analisa.

- Total gula, dihitung menggunakan kurva standar dan spektrofotometer dengan melarutkan sari tebu hijau denganfenol $5 \%$ dan $5 \mathrm{ml}$ larutan $\mathrm{H}_{2} \mathrm{SO}_{4}$. Selanjutnya didiamkan 10 menit dan diukur dengan spektrofotometer.

- Viskositas, dihitung menggunakan viscometer akfield RVT dengan memasukkan sampel pada beaker glass dalam viscometer.

- Warna, dihitung menggunakan color reader, dengan memasukkan sari tebu hijau pada color reader maka akan muncul nilai kecerahan $\left(L^{*}\right)$, kemerahan $\left(a^{*}\right)$, dan kekuningan $\left(b^{*}\right)$.

\section{Analisa Data}

Analisis data menggunakan analisis ANOVA. Apabila ada beda nyata maka dilakukan uji lanjut BNT dan apabila interaksi kedua faktor menunjukkan beda nyata, maka dilanjutkan dengan uji DMRT.

\section{Perlakuan Terbaik}

Pemilihan perlakuan terbaik dilakukan berdasarkan total mikroba (TPC) terendah, yaitu berdasarkan perlakuan pasteurisasi non thermal dengan menggunakan PEF sistem kontinyu.

\section{HASIL DAN PEMBAHASAN}

\section{Karakteristik Bahan Perlakuan}

Parameter-parameter yang dianalisa pada sari tebu hijau yaitu Total Plate Count (TPC) atau total cemaran mikroba, total padatan terlarut (TPT), total gula, viskositas, dan warna. Berdasarkan hasil analisa sari tebu hijau sebelum perlakuan dengan Pulsed Electric Field (PEF) yang ditunjukan pada Tabel 1. 
Tabel 1. Karakteristik Sari Tebu Hijau

\begin{tabular}{lccc}
\hline Karakteristik & Nilai & Literatur & Satuan \\
\hline Total Plate & $6,79 \times$ & $4,25 \times 10^{10}$ & $\mathrm{cfu} / \mathrm{ml}$ \\
Count (TPC) & $10^{7}$ & $*$ & \\
Total padatan & 17,05 & $16^{* *}$ & ${ }^{\circ}$ Brix \\
terlarut & & & \\
Total gula & 16,595 & - & $\%$ \\
Viskositas & 5,5 & $2,03^{* *}$ & $\mathrm{Cp}$ \\
Warna & & & \\
$\mathrm{L}^{*}$ & 22,95 & - & - \\
$\mathrm{a}^{*}$ & 6,90 & - & - \\
$\mathrm{b}^{*}$ & 6,75 & - & - \\
\hline Keterangan : & \\
$(2000)$ & Muharani $\left.(2011),{ }^{* *}\right)$ & Yusof et al \\
& &
\end{tabular}

Nilai Total Plate Count sari tebu hijau pada penelitian yaitu sebesar $6,79 \times 10^{7} \mathrm{cfu} / \mathrm{ml}$ dibandingkan dengan literatur menurut Muharani (2011) adalah sebesar $4,25 \times 10^{10} \mathrm{cfu} / \mathrm{ml}$, terjadi perbedaan nilai total mikroba. Sedangkan pada pengukuran nilai $\mathrm{pH}$ pada sari tebu hijau sebesar 5,54 dan pada literatur menurut Yusof (2000) sebesar 5,7. Hal tersebut dikarenakan perbedaan waktu panen atau daerah tanam, sehingga terjadi perbedaan nilai TPC dan $\mathrm{pH}$ dapat mengalami perbedaan yang cukup signifikan. Terjadi perbedaan yang cukup signifikan ini juga terjadi pada nilai karakteristik viskositas, yaitu pada penelitian mendapatkan nilai 5,5 Cp, sedangkan pada literatur menurut Yusof (2000) sebesar 2,03, selain karena waktu panen dan daerah tanah yang berbeda viskositas sari tebu hijau juga dipengaruhi oleh waktu tunggu pengujian

Pada total padatan terlarut sudah mendekati nilai yang ada pada literatur menurut Yusof (2000), total padatan terlarut pada penelitian sebesar $17,05{ }^{\circ}$ Brix dan nilai total padatan terlarut pada literatur sebesar $16{ }^{\circ}$ Brix. Terjadi perbedaan yang cukup signifikan ini juga terjadi pada nilai karakteristik viskositas, yaitu pada penelitian mendapatkan nilai $5,5 \mathrm{Cp}$, sedangkan pada literatur menurut Yusof (2000) sebesar 2,03.

\section{Total Plate Count (TPC)}

Total Plate Count (TPC) merupakan jumlah total mikroba yang terkandung pada sari tebu hijau. Pada uji ANOVA menunjukkan bahwa tegangan dan frekuensi tidak berpengaruh signifikan terhadap TPC sari tebu hijau. Grafik rerata TPC dapat dilihat pada Gambar 4.

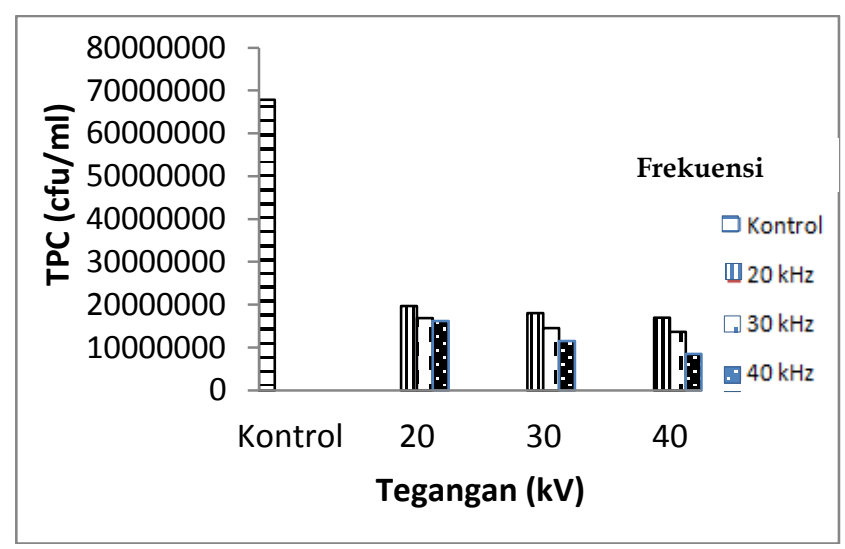

Gambar 4. Grafik Hubungan Tegangan (kV) dan Frekuensi $(\mathrm{kHz})$ terhadap TPC (cfu/ml) Sari Tebu Hijau

Pada Gambar 4 menunjukkan penurunan total mikroba dengan adanya penambahan tegangan dan frekuensi pada perlakuan pulsed electric field (PEF). Total mikroba pada kontrol yaitu $6,79 \times 10^{7}$ (cfu/ml). Total mikroba pada sari tebu hijau berkisar antara $8,5 \times 10^{6} \mathrm{cfu} / \mathrm{ml}$ $1,97 \times 10^{7} \mathrm{cfu} / \mathrm{ml}$. Sedangkan total mikroba paling banyak yaitu pada tegangan $40 \mathrm{kV}$ dengan frekuensi $40 \mathrm{kHz}$ sebesar $8,5 \times 10^{6}$ (cfu/ml). Nilai tersebut masih di bawah standart SNI sari buah, menurut SNI 7388-2009 yaitu $1 \times 10^{4} \mathrm{cfu} / \mathrm{ml}$. Berdasarkan grafik tersebut dapat dilihat bahwa semakin tinggi tegangan dan frekuensi maka semakin banyak penurunan mikroba sari tebu hijau. Menurut Barbosa, et al., (1999) menyatakan bahwa penurunan mikroorganisme berbanding lurus dengan besar tegangan, frekuensi dan waktu pasteurisasi.

\section{Efektivitas Kematian Mikroba}

Penurunan mikroba paling banyak pada sari tebu hijau menggunakan PEF sebesar $87,48 \%$ yaitu pada tegangan $40 \mathrm{kV}$ dengan jumlah total mikroba sebanyak $8,5 \times 10^{6} \mathrm{cfu} / \mathrm{ml}$. Efektivitas penurunan mikroba pada sari tebu menggunakan PEF secara keseluruhan dapat dilihat pada Tabel 2. 
Tabel 2. Efektivitas Penurunan Total Plate Count (TPC)

\begin{tabular}{ccc}
\hline $\begin{array}{c}\text { Tegangan } \\
\text { (kV) }\end{array}$ & TPC (cfu/ml) & $\begin{array}{c}\text { Efektivitas } \\
\text { Kematian Mikroba } \\
\text { (\%) }\end{array}$ \\
\hline 20 & $1,62 \times 10^{7}$ & 76,14 \\
30 & $1,16 \times 10^{7}$ & 82,99 \\
40 & $8,50 \times 10^{6}$ & 87,48 \\
\hline
\end{tabular}

Tabel 2 terlihat bahwa semakin tinggi tegangan yang diberikan maka efektivitas kematian mikroba semakin banyak. Hal ini karena perlakuan kejut listrik tegangan tinggi pada sari tebu hijau dapat mengganggu kerja dan fungsi fisiologis pada mikroba, sehingga terjadi penurunan mikroba. Selain hal tersebut kejut listrik tegangan tinggi pada sari tebu hijau juga berpengaruh terhadap rusaknya struktur sel mikroba. Andriawan, dkk., (2015) yang menyatakan bahwa pemberian kejutan listrik tegangan tinggi pada bahan dapat menyebabkan terjadinya penurunan jumlah mikroorganisme tanpa adanya efek panas. Hal ini disebabkan karena adanya peningkatan aktivitas metabolisme yang terlalu tajam sehingga menggangu kerja dan fungsi fisiologis mikroba.

\section{Potential Decimal Reduction Time (D)}

Potential Decimal Reduction Time (D) merupakan waktu dalam satuan detik pada tegangan tertentu yang dibutuhkan untuk menurunkan/ membunuh hampir $90 \%$ dari jumlah mikroba yang ada. Rumus potential decimal reduction time (D) (Sumarlan, dkk., 2014):

$$
\mathrm{D}=-\frac{t}{\log \left(\frac{N}{N 0}\right)}
$$

Grafik potential decimal reduction time dapat dilihat pada Gambar 5.

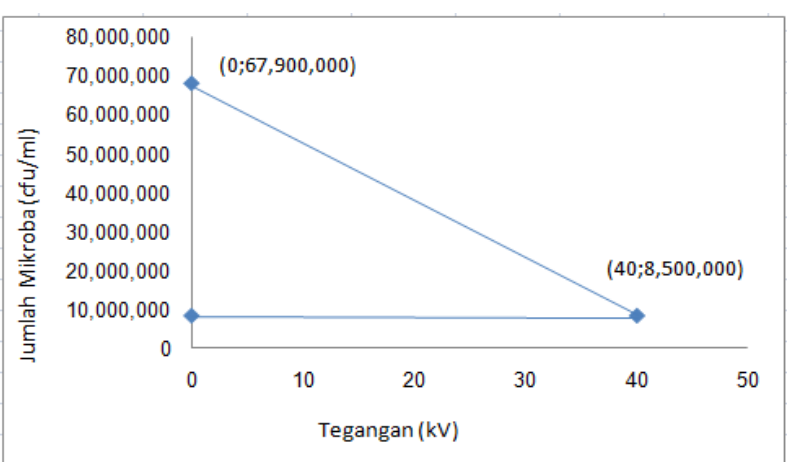

Gambar 5. Grafik Potential Decimal Reduction Time (D)

Pada Gambar 5 jumlah mikroba awal yaitu sebesar $6,79 \times 10^{7} \mathrm{cfu} / \mathrm{ml}$ yang ditunjukkan pada titik $\left(0,6,79 \times 10^{7}\right)$ dan penurunan mikroba pada tegangan $40 \mathrm{kV}$ sebesar $8,5 \times 10^{6} \mathrm{cfu} / \mathrm{ml}$ yang ditunjukkan pada titik $\left(40 ; 8,5 \times 10^{6}\right)$ menurunkan mikroba sebesar 0,9 log cycle. Penurunan total mikroba pada sari tebu hijau tidak mencapai $90 \%$ atau 1 log cycle, hal ini dapat terjadi karena tegangan dan frekuensi yang diberikan selama perlakuan kurang tinggi serta kurangnya lama waktu perlakuan PEF, sehingga pada penelitian ini tidak mencapai 1 log cycle atau $90 \%$.

\section{Laju Kematian Mikroba (Lethal Rates)}

Lethal rates merupakan laju kematian mikroorganisme tiap satuan waktu akibat kejutan listrik tegangan tinggi pada suatu bahan pangan. Laju kematian mikroba dapat digambarkan dalam sebuah grafik yang nilainya sama dengan nilai kemiringan (slope) dari grafik tersebut (Sumarlan, dkk., 2014). Grafik laju penurunan mikroba dapat dilihat pada Gambar 6.

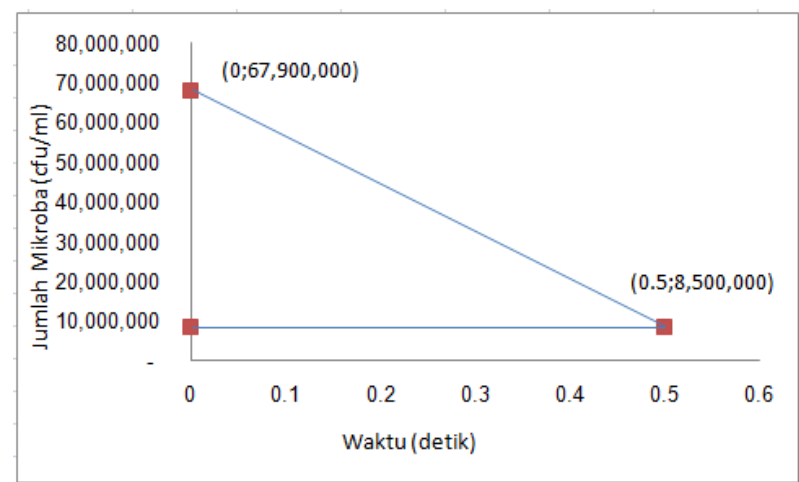

Gambar 6. Grafik Laju Penurunan Mikroba 
Pada grafik laju kematian mikroba menunjukkan penurunan jumlah total mikroba pada sari tebu hijau. Kemiringan grafik atau gradient merupakan laju kematian mikroorganisme (lethal rates) yang dapat dihitung dengan rumus sebagai berikut:

$$
\begin{aligned}
\text { Slope }=\frac{\Delta x}{\Delta y} & =\frac{67900000-8500000}{0,5-0} \\
& =1,19 \times 10^{8}(\mathrm{cfu} / \mathrm{ml}) / \text { detik }
\end{aligned}
$$

Berdasarkan perhitungan diatas dapat diketahui bahwa dengan menggunakan perlakuan PEF bertegangan $40 \mathrm{kV}$ dapat menginaktivasi mikroba sebesar $1,19 \times 10^{8}$ (cfu/ml). Persamaan grafiknya mengikuti model persamaan linier sebagai berikut :

$y-y 1=m(x-x 1)$

$x$ adalah waktu (detik)

y adalah jumlah penurunan mikroba (cfu/ml)

Grafik laju kematian mikroba pada sari tebu hijau menggunakan PEF melalui titik $(0,67900000)$ yang merupakan nilai NO yaitu sebagai perlakuan kontrol didapatkan:

$$
\begin{aligned}
y-6,79 \times 10^{7} & =-1,19 \times 10^{8}(x-0) \\
y & =6,79 \times 10^{7}-1,19 \times 10^{8}
\end{aligned}
$$

$\mathrm{m}$ gradient yang merupakan lethal rates, apabila grafik mengalami penurunan maka nilainya negatif.

\section{Total Padatan Terlarut (TPT)}

Total padatan terlarut (TPT) menggambarkan tentang kandungan bahan-bahan yang terlarut dalam larutan. Sebagian besar total padatan pada minuman ringan adalah gula sehingga perubahan total gula akan menyebabkan perubahan juga pada total padatan terlarut (Yusuf 2002). Total padatan terlarut dinyatakan dalam bentuk ${ }^{\circ}$ Brix, yaitu skala berdasarkan persentase berat sukrosa didalamlarutan (minuman). Berdasarkan hasil uji ANOVA menunjukkan bahwa tegangan dan frekuensi tidak berpengaruh signifikan terhadap total padatan terlarut (TPT) sari tebu hijau. Grafik rerata TPT dapat dilihat pada Gambar 7 yang menunjukkan total padatan terarut sari tebu hijau setelah perlakuan berkisar
$12,4{ }^{\circ}$ Brix - $13,7{ }^{\circ}$ Brix. Grafik tersebut menunjukkan adanya penurunan total padatan terlarut pada setiap perlakuan. Penurunan total padatan terlarut karena tinggi rendahnya konsentrasi enzim yang bereaksi dengan perubahan tegangan dan frekuensi yang diberikan oleh PEF. Kemungkinan setelah adanya pengenaan pada bahan dapat mengakibatkan enzim menjadi turun sehingga TPT sari tebu menjadi lebih rendah dibandingkan kontrol. Menurut Darmajana, dkk., (2008) yang mengatakan bahwa semakin tinggi konsentrasi enzim maka akan semakin tinggi pula total padatan terlarut atau akan semakin banyak pula gula sederhana yang dihasilkan.

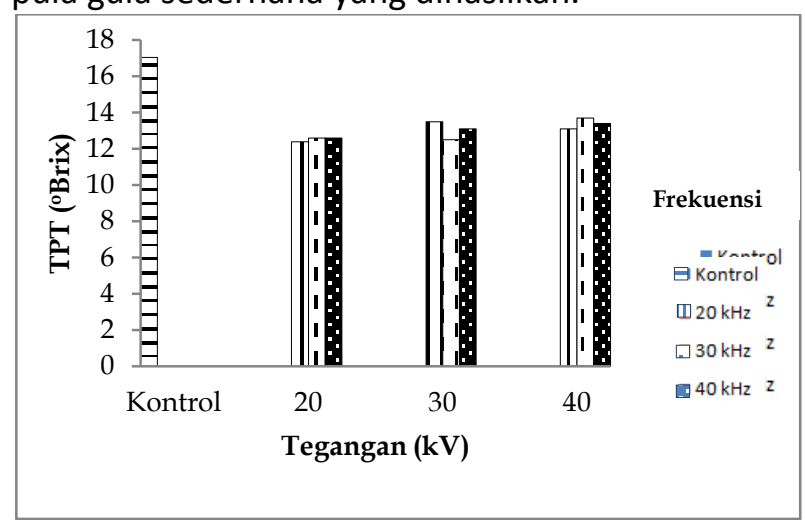

Gambar 7. Grafik Hubungan Tegangan (kV) dan Frekuensi $(\mathrm{kHz})$ terhadap rerata TPT ( $\left.{ }^{\circ} \mathrm{Brix}\right)$ Sari Tebu Hijau

\section{Total Gula}

Total gula merupakan jumlah gula reduksi dan non reduksi yang terkandung dalam sari tebu hijau. Berdasarkan hasil uji ANOVA menunjukkan bahwa tegangan dan frekuensi tidak berpengaruh signifikan terhadap total gula sari tebu hijau. Grafik rerata total gula dapat dilihat pada Gambar 8 yang menunjukkan total gula setelah perlakuan berkisar $11,41 \%-12,30 \%$. Terjadi penurunan pada setiap perlakuan sari tebu hijau, hal ini karena pemberian variasi tegangan dan frekuensi pada sari tebu hijau. Semakin tinggi tegangan yang diberikan pada PEF dapat meningkatkan suhu pada sari tebu hijau, sehingga sari tebu hijau mendapatkan perlakuan panas dengan adanya kejut listrik bertegangan tinggi, hal ini yang mengakibatkan terjadinya penurunan total gula pada sari tebu hijau. Menurut Sumarlan, dkk., $(20,14)$ menyatakan bahwa tegangan yang tinggi 
dapat menyebabkan terhidrolisisnya gula sederhana sehingga kadar gula akan menurun.

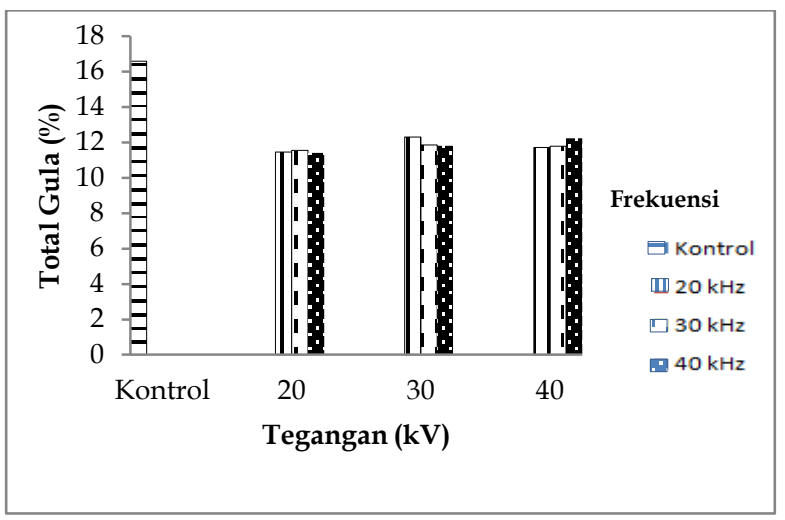

Gambar 8. Grafik Hubungan Tegangan (kV) dan Frekuensi $(\mathrm{kHz})$ terhadap rerata Total Gula (\%) Sari Tebu Hijau

\section{Viskositas}

Berdasarkan hasil uji ANOVA menunjukkan bahwa tegangan dan frekuensi PEF tidak berpengaruh signifikan terhadap viskositas sari tebu hijau. Menurut Muslim (2013) menyatakan bahwa perlakuan pasteurisasi nontermal dengan perlakuan kejut listrik tidak menyebabkan perubahan viskositas yang nyata dari viskositas susu hasil pasteurisasi. Grafik rerata viskositas dapat dilihat pada Gambar 9.

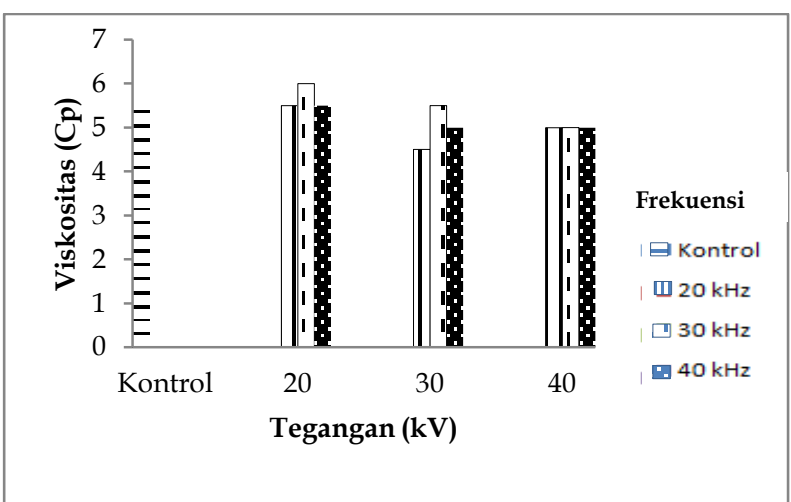

Gambar 9. Grafik Hubungan Tegangan (kV) dan Frekuensi $(\mathrm{kHz})$ terhadap rerata Viskositas (Cp) Sari Tebu Hijau

Pada Gambar 9 menunjukkan bahwa viskositas sari tebu hijau setelah perlakuan berkisar 4,5Cp- $6 \mathrm{Cp}$. Grafik tersebut menunjukkan adanya penurunan dan kenaikan pada setiap perlakuan. Kenaikan dan penurunan viskositas sari tebu hijau terjadi karena partikel-partikel pada sari tebu hijau berkaitan dengan pektin sehingga tingkat viskositas akan meningkat. Menurut Tors (2006) mengatakan bahwa nilai viskositas akan meningkat apabila partikel-partikel yang ada dalam sari buah seperti serat, air, dan komplek protein yang akan berikatan dengan pektin sehingga tingkat viskositas akan meningkat.

\section{Warna}

Culver (2008) menyatakan bahwa warna merupakan salah satu karakteristik yang sangat menentukan kualitas dari suatu produk pangan. Sehingga pada produk pangan perlu menjaga karakteristik tersebut. Pengukuran nilai warna terbagi menjadi tiga yaitu kecerahan (L), kemerahan $\left(a^{*}\right)$, dan kekuningan $\left(b^{*}\right)$.

\section{Nilai Kecerahan $\left(L^{*}\right)$}

Berdasarkan hasil uji ANOVA terlihat bahwa tegangan dan frekuensi tidak berpengaruh signifikan terhadap nilai kecerahan $\left(L^{*}\right)$ sari tebu hijau. Grafik rerata nilai kecerahan $\left(L^{*}\right)$ dapat dilihat pada Gambar 10.

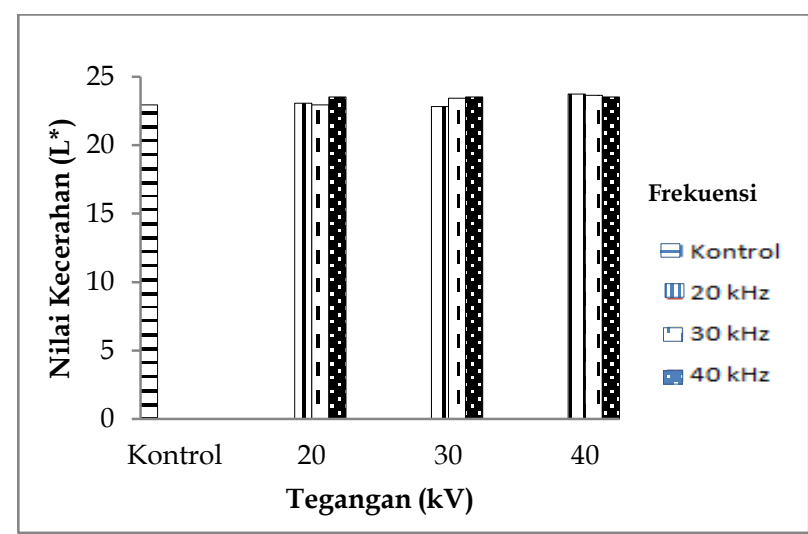

Gambar 10. Grafik Hubungan Tegangan (kV) dan Frekuensi $(\mathrm{kHz})$ terhadap rerata Nilai Kecerahan (L*) Sari Tebu Hijau

Pada Gambar 10 menunjukkan nilai kecerahan sari tebu hijau setelah perlakuan berkisar 22,85-23,75. Perubahan warna kecerahan juga dapat dipengaruhi oleh reaksi pencoklatan nonenzimatik. Pada proses PEF beberapa enzim berkembang sehingga tingkat kecerahan 
meningkat. Moyer, et al,. (1980) menyatakan bahwa reaksi pencokelatan nonenzimatik dapat mempengaruhi perubahan warna hal ini dikarenakan oleh reaksi asam amino, gula dan asam organik. Selama proses pasteurisasi baik PEF ataupun pemanasan beberapa enzim berkembang sehingga kondisi inilah yang menyebabkan tingkat kecerahan semakin meningkat.

\section{Nilai Kemerahan ( $\left.a^{*}\right)$}

Berdasarkan hasil uji ANOVA menunjukkan bahwa tegangan dan frekuensi tidak berpengaruh signifikan nyata terhadap nilai kemerahan ( $\left.a^{*}\right)$ sari tebu hijau. Grafik rerata nilai kemerahan (a*) dapat dilihat pada Gambar 11.

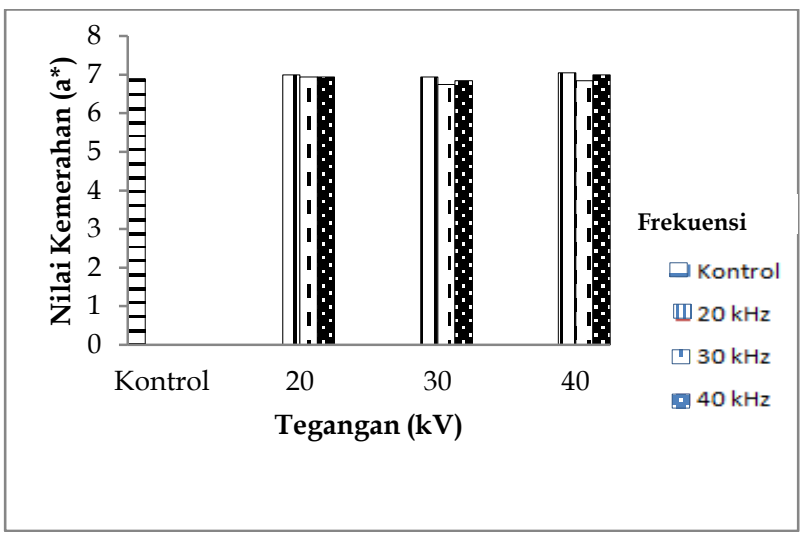

Gambar 11. Grafik Hubungan Tegangan (kV) dan Frekuensi $(\mathrm{kHz})$ terhadap rerata Kemerahan $\left(\mathrm{a}^{*}\right)$ Sari Tebu Hijau

Pada Gambar 11 menunjukkan nilai kemerahan sari tebu hijau setelah perlakuan berkisar 6,85-7,05. Penurunan dan peningkatan nilai kemerahan pada sari tebu hijau terjadi karena adanya pengaruh proses kejut listrik pada PEF. Peningkatan tegangan pada PEF berpengaruh pada peningkatan suhu, sehingga warna kemerahan pada sari tebu hijau meningkat.

\section{Nilai Kekuningan (b*)}

Berdasarkan hasil uji ANOVA menunjukkan bahwa tegangan dan frekuensi tidak berpengaruh signifikan terhadap nilai kekuningan $\left(b^{*}\right)$ sari tebu hijau. Rerata nilai kekuningan $\left(b^{*}\right)$ dapat dilihat pada Gambar 12.

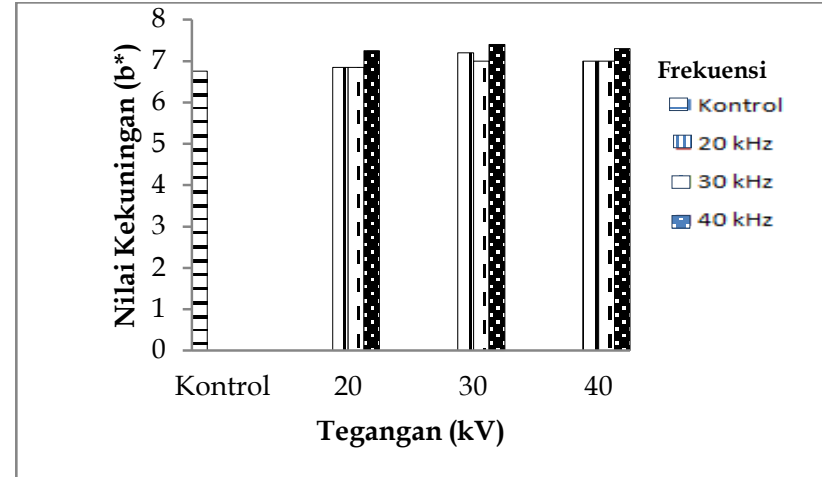

Gambar 12. Grafik Hubungan Tegangan (kV) dan Frekuensi $(\mathrm{kHz})$ terhadap rerata Kekuningan $\left(\mathrm{b}^{*}\right)$ pada Sari Tebu Hijau

Pada Gambar 12 menunjukkan nilai kekuningan sari tebu hijau setelah perlakuan berkisar 6,85-7,4. Perubahan warna yang terjadi pada sari tebu hijau juga karena terjadinya degradasi pigmen klorofil. Hal ini sesuai penelitian Yusof, et al., ( 2000) yang menyatakan bahwa klorofil merupakan pigmen utama pada sari tebu. Keberadaan klorofil sebagai pigmen utama inilah yang menyebabkan sari tebu memiliki warna hijau dan memungkinkan untuk ikut berperan terhadap terjadinya degredasi warna.

\section{Perlakuan Terbaik}

Setelah melakukan perhitungan menggunakan ANOVA tegangan dan frekuensi yang rendah pada PEF sistem kontinyu ini tidak berpengaruh nyata terhadap TPC, TPT, total gula, viskositas dan warna sari tebu hijau sari tebu hijau sehingga penentuan perlakuan terbaik pada pelakuan menggunakan hasil uji Total Plate Count (TPC) paling sedikit. Hal ini karena dengan jumlah total mikroba yang semakin sedikit dalam sari tebu hijau akan mengurangi resiko cemaran pada sari tebu hijau. Namun berdasarkan penentuan tersebut perlakuan terbaik menurut parameter TPC adalah tegangan $40 \mathrm{kV}$ dengan frekuensi 40 $\mathrm{kHz}$. Hasil perlakuan terbaik dapat dilihat pada Tabel 3. 
Tabel 3. Karakteristik Perlakuan Terbaik dari Sari Tebu Hijau Menggunakan Pulsed Electric Field (PEF)

\begin{tabular}{|c|c|c|c|}
\hline $\begin{array}{l}\text { Karakteri } \\
\text { stik }\end{array}$ & $\begin{array}{c}\text { Tanpa } \\
\text { Perlaku } \\
\text { an }\end{array}$ & $\begin{array}{c}\text { Perlakuan } \\
\text { Terbaik } \\
(\mathrm{V}=40 \mathrm{kV} \\
\text { dan } \mathrm{F}=40 \\
\mathrm{kHz})\end{array}$ & $\begin{array}{c}\text { Keterang } \\
\text { an }\end{array}$ \\
\hline $\begin{array}{l}\text { TPC } \\
\text { (cpu/ml) }\end{array}$ & $\begin{array}{c}6,79 x \\
10^{7}\end{array}$ & $8,5 \times 10^{6}$ & Minimal \\
\hline $\begin{array}{l}\text { TPT } \\
\text { ( }{ }^{\circ} \text { Brix) }\end{array}$ & 17,05 & 13,4 & Maksimal \\
\hline $\begin{array}{l}\text { Total } \\
\text { Gula(\%) }\end{array}$ & 16,595 & 12,24 & Maksimal \\
\hline $\begin{array}{l}\text { Viskosita } \\
\text { s (Cp) } \\
\text { Warna }\end{array}$ & 5,5 & 5 & Maksimal \\
\hline$L^{*}$ & 22,95 & 23,55 & Maksimal \\
\hline$a^{*}$ & 6,9 & 7 & Minimal \\
\hline$b^{*}$ & 6,75 & 7,3 & Maksimal \\
\hline
\end{tabular}

\section{KESIMPULAN}

Pada penelitian sari tebu hijau dengan perlakuan tegangan dan frekuensi pulsed electric field (PEF) tidak berpengaruh nyata terhadap Total Plate Count (TPC), total padatan terlarut, total gula, viskositas, dan warna sari tebu hijau. Perlakuan terbaik yaitu perlakuan tegangan $40 \mathrm{kV}$ dengan frekuensi $40 \mathrm{kHz}$. Hasil perlakuan terbaik mendapatkan TPC sebesar $8,5 \times 10^{6} \mathrm{cfu} / \mathrm{ml}$ dengan penurunan sebesar $87,48 \%$ dan mampu mereduksi 0,9 log cycle. Laju kematian mikroba sebesar $1,19 \times 10^{8}(\mathrm{cfu} / \mathrm{ml}) /$ detik, nilai TPT sebesar 13,4 oBrix, total gula sebesar $12,24 \%$, viskositas sebesar $5 \mathrm{Cp}$, dan karakteristik warna yaitu, nilai kecerahan (L*) sebesar 23,55, nilai kemerahan $\left(a^{*}\right)$ sebesar 7 , dan nilai kekuningan (b*) sebesar 7,3 .

\section{DAFTAR PUSTAKA}

Anonim.1998. Deskripsi Tebu Varietas PS 862. P3GI. Pasuruan.

Anonim. 2008. Konsep Peningkatan Rendeman Tebu untuk Mendukung Proses Akselerasi Industri Gula Nasional.
<http://p3gi.net/images/opini/Konsep\%20Peningk atan\% Rendemen.pdf>.

Diakses tanggal 20 Januari 2015.

Aguiló-Aguayo, I., Soliva-Fortuny, R., and MartinBelloso, O. 2010. Optimizing critical highintensity pulsed electric fields treatments for reducing pectolytic activity and viscosity changes in watermelon juice. European Food Research and Technology, 231, 509-517.

Andriawan, V, dan Bambang S. 2015. "Susu Listrik" Alat Pasteurisasi Susu Kejut Listrik Tegangan Tinggi (Pulsed Electric Field) Menggunakan Transformator Tegangan Tinggi dan Inverter. Jurnal Keteknikan Pertanian Vol 3 (2). Universitas Brawijaya. Malang.

Aronsson, Kristina., M. Lindgren, Bengt R. Johanssonb, Ulf Ronner. 2001. Inactivation Of Microorganisms Using Pulsed Electric Fields: The Influence Of Process Parameters On Escherichia coli, Listeria innocua, Leuconostoc mesenteroides and Saccharomyces cereisiae. Innovative Food Science \& Emerging Technologies Vol 2. Swedish Institute of Food and Biotechnology. Goteborg. Sweden.

Barbosa-Cánovas, G. V., U. R Pothakamury, E. Palou, B.G. Swanson. 1999. Preservation of Foods with Pulsed Electric Fields. Academic Press. San Diego.

Darmajana, Doddy A., Agustina W dan Wartika. 2008. Pengaruh Konsentrasi Enzim $\alpha$ Amilase terhadap Sifat Fisik Organoleptik Filtrat Bubur Pisang (Bahan Pembuatan Tepung Pisang Instan). Unila Press. Lampung.

Honig, P.1986. Principles of Sugar Technology. Elsevier Press. New York.

Muslim, Choirul. La Choviya Hawa dan Bambang Dwi Argo. 2013. Pasteurisasi Non-Termal Pada Susu Sapi Segar untuk Inaktivasi Bakteri Staphylococcus aureus Berbasis Pulsed Electric Field (PEF). Jurnal Keteknikan Pertanian Tropis dan Biosistem Vol 1(1). Universitas Brawijaya. Malang.

Moyer, J.C. and H.C. Aitken. 1980. Apple juice. Dalam P.E. Nelson, and D.K. Tressler,. (eds). Fruit and Vegetable Juice Processing 
Technology. 212-267. Avi Publishing Co., Inc, Wesport-USA.Muharani. 2011. Perkembangan Bakteri Probiotik dan Nilai Organoleptik minuman Fermentasi dari Media Nira Aren (Arenga Pinnata Merr), Nira Tebu (Saccharum officinarum L) dan Air Kelapa (Cocos Nucifera L.). Universitas Andalas. Padang.

Muharani. 2011. Perkembangan Bakteri Probiotik dan Nilai Organoleptik Minuman Fermentasi dari Media Nira Aren (Arenga pinnata Merr), nira Tebu (Saccharum officinarum L.) dan Air Kelapa (Cocos nucifera L.). Universitas Andalas. Padang. Skripsi.

Rahmad, A., Susinggih W., Nimas M. S. S. 2013. Kajian Analisa Kelayakan Pengembangan Usaha dengan Diversifikasi Produk Olahan Tebu di CV. Kurnia Agung. Malang.

Standart Nasional Indonesia. 2009. Batas Maksimum Cemaran Mikroba Dalam
Pangan. Badan Standarisasi Nasional. Jakarta.

Sumarlan, Sumardi H., Riska Dwi April Liani, Rini Yulianingsih dan Dina W. Indriani. 2014. Pengaruh Tegangan Dan Frekuensi Terhadap Karakteristik Dan Penurunan Jumlah Mikroorganisme Sari Buah Belimbing (Averrhoa Carambola L) Menggunakan Pulsed Electric Field (PEF). Jurnal Teknologi Pertanian Vol 15(1). Universitas Brawijaya. Malang.

Trost, E.G. 2006. Protein Beverages A Healhty Alternative. Dalam Seminar Nsional Teknologi 2007 (SNT 2007). ISSN:19989777.

Yusof S, Shian L. S., Osman A. 2000. Changes In Quality Of Sugarcane Juice Upon Delayed Extraction And Storage. Food Chemistry 68:395-401. Universiti Putra Malaysia. Malaysia. 